Portland State University

PDXScholar

2-17-2009

\title{
From Urban Frontier to Metropolitan Region: Oregon's Cities from 1870 to 2008
}

Carl Abbott

Portland State University, d3ca@pdx.edu

Follow this and additional works at: https://pdxscholar.library.pdx.edu/usp_fac

Part of the Urban Studies and Planning Commons

Let us know how access to this document benefits you.

\section{Citation Details}

Abbott, Carl, "From Urban Frontier to Metropolitan Region: Oregon's Cities from 1870 to 2008" (2009). Urban Studies and Planning Faculty Publications and Presentations. 36.

https://pdxscholar.library.pdx.edu/usp_fac/36

This Presentation is brought to you for free and open access. It has been accepted for inclusion in Urban Studies and Planning Faculty Publications and Presentations by an authorized administrator of PDXScholar. Please contact us if we can make this document more accessible: pdxscholar@pdx.edu. 


\section{Toward One

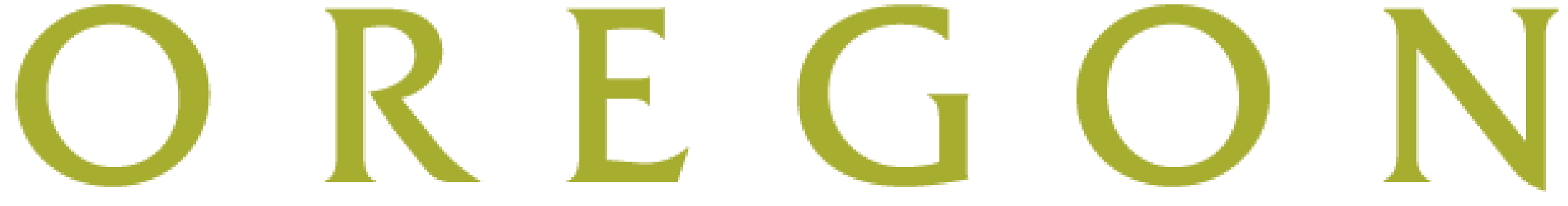 \\ Rural-Urban Interdependence}




\title{
From Urban Frontier to Metropolitan Region: Oregon's Cities from 1870 to 2008
}

\author{
Carl Abbott \\ Portland State University \\ abbottc@pdx.edu
}




\section{Three Eras of Oregon Cities}

- Portland ascendant: 1870-1920

- Oregon in balance: 1920-1970

- The long arm of the metropolis: 1970-2008 


\section{Who's on first?}

Portland has been Oregon's largest city through the entire era of statehood.

Three cities have occupied second place: Salem, Astoria, and Eugene.

Ten additional cities have traded off among the top five. In chronological order they are: Oregon City, Jacksonville, The Dalles, Albany, Baker City, Pendleton, Medford, Klamath Falls, Corvallis, and Bend. 


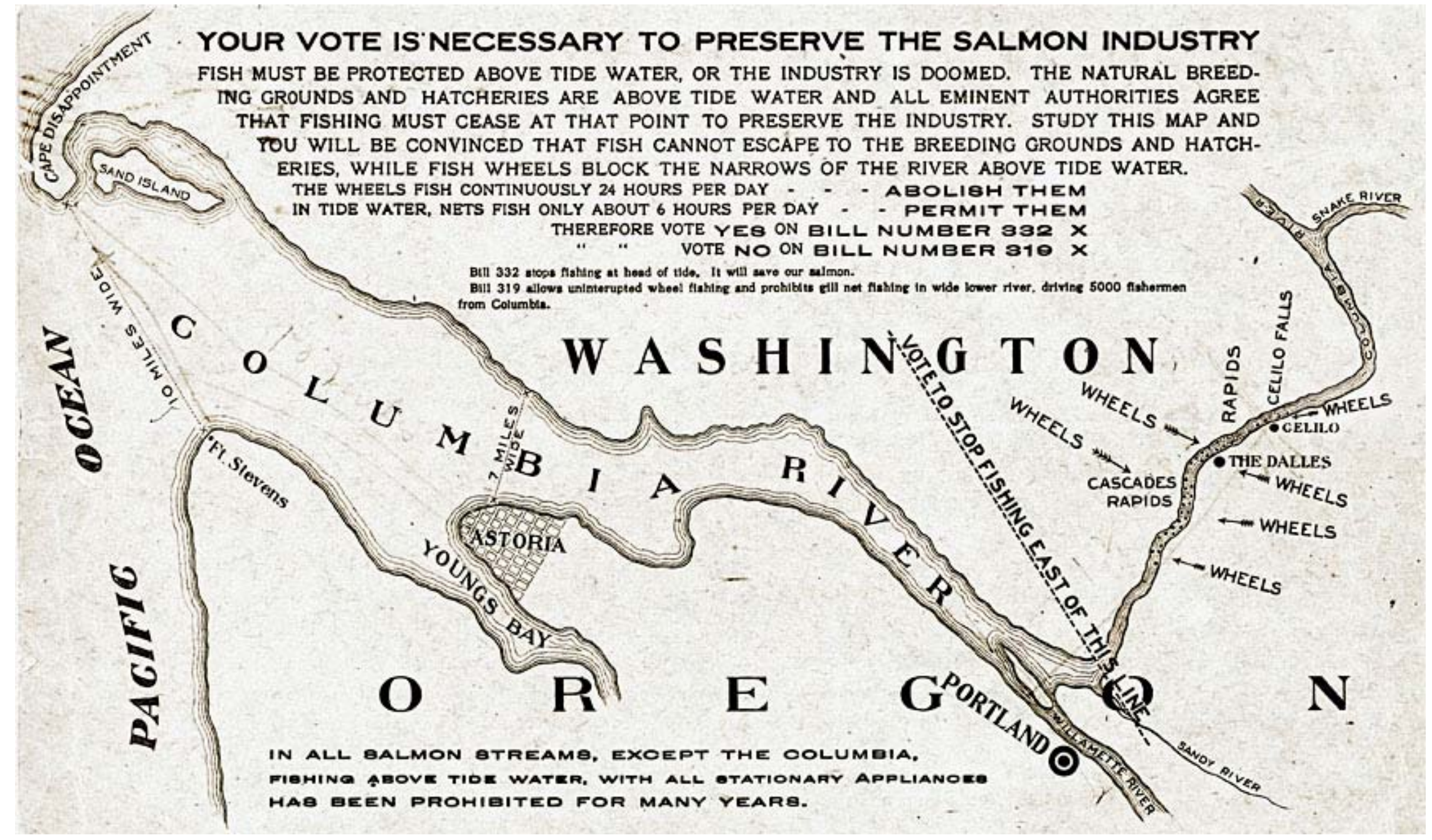




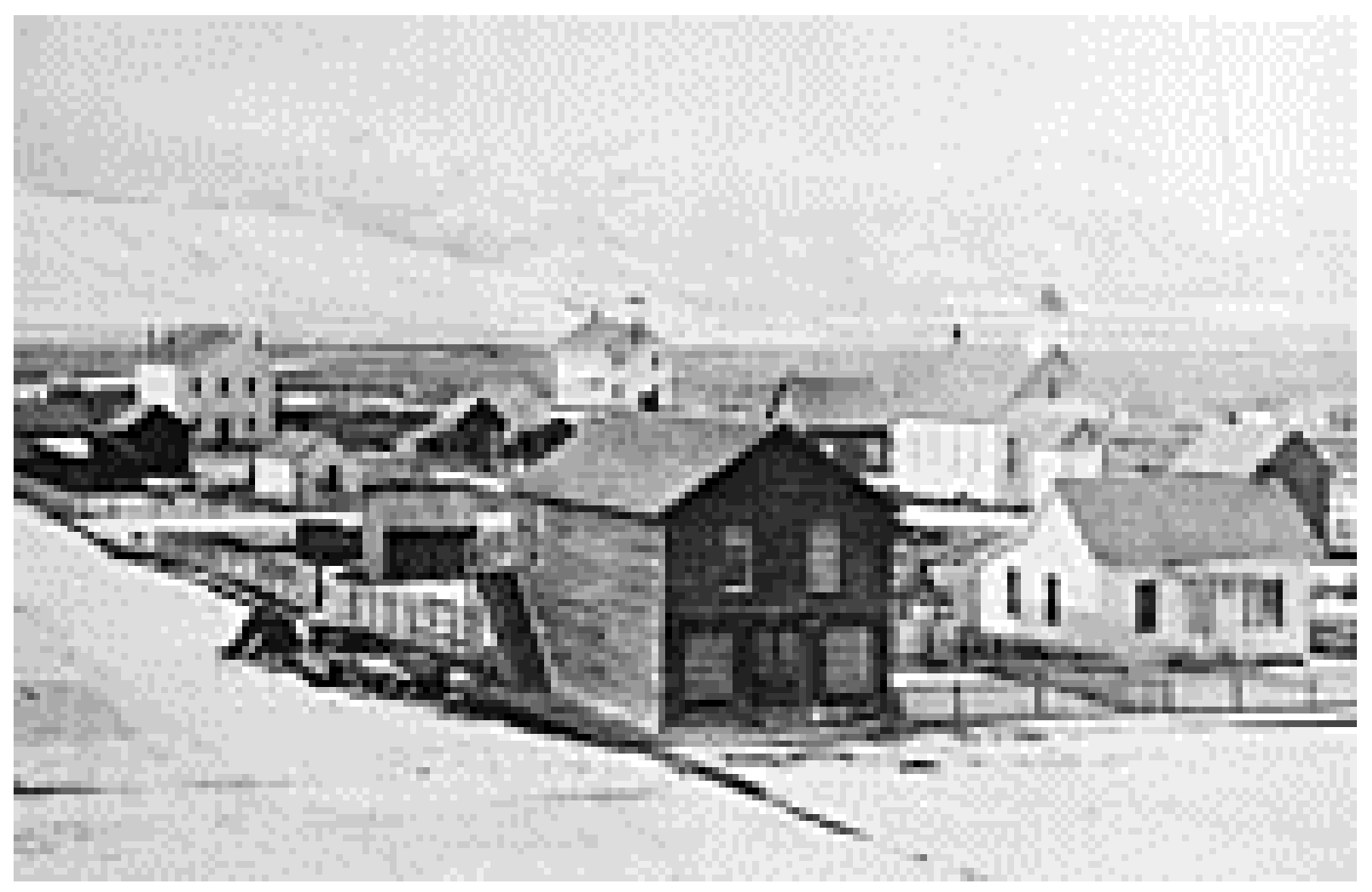




\section{Portland: Gateway to the Northwest}

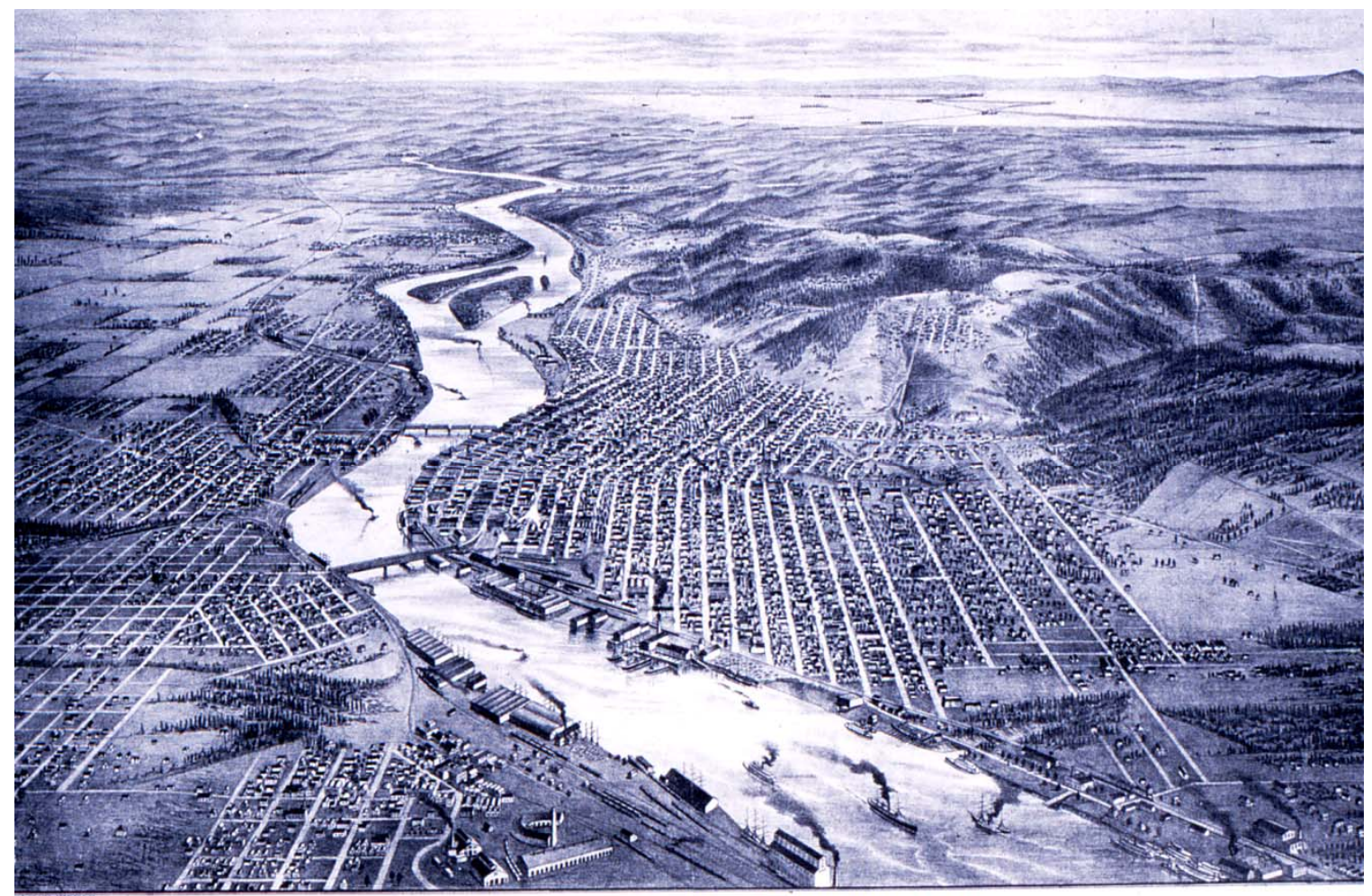

PORTL.AND, OREGON,AND ITS SLRROUNDINGS.1889. 


\section{Transportation Center}

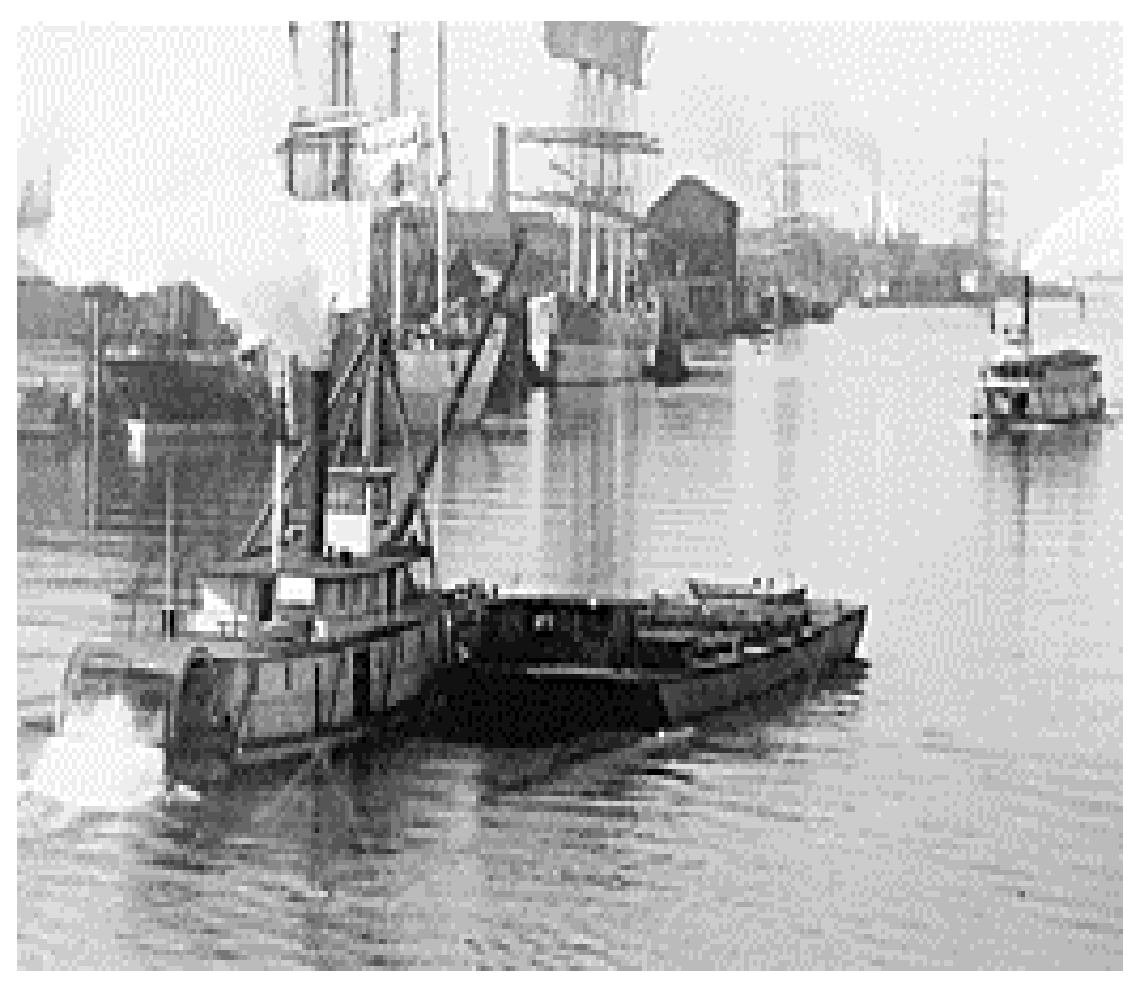




\section{Transportation Center}

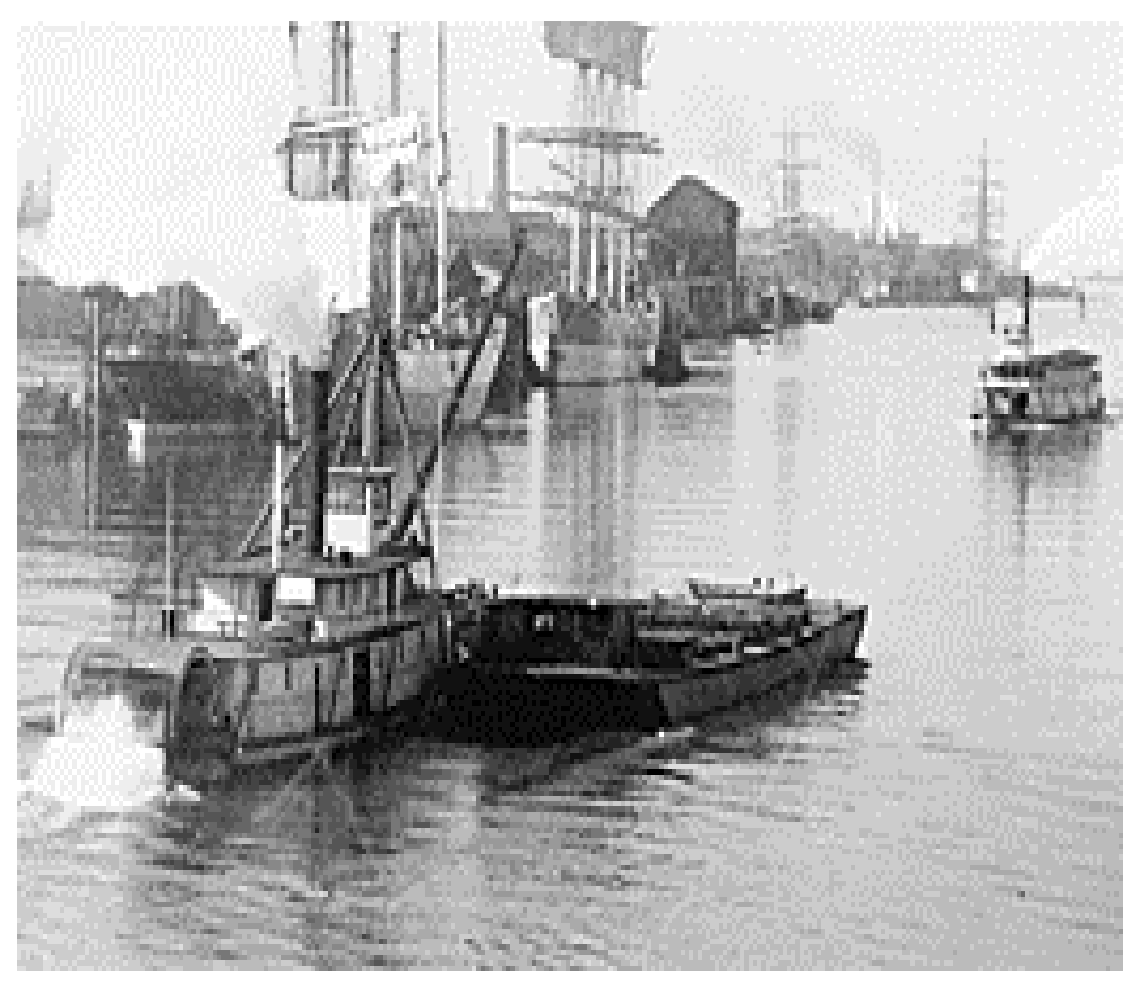




\section{Manufacturing Powerhouse}

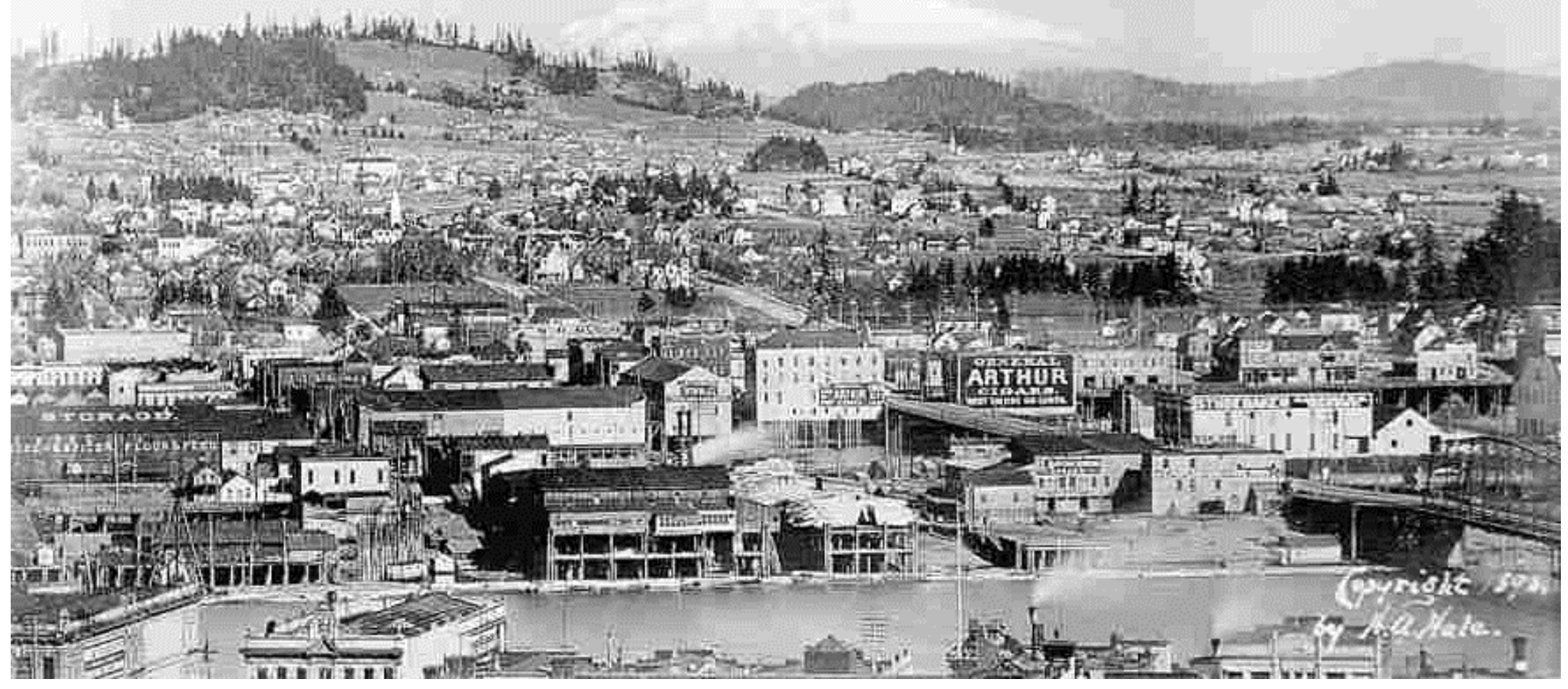




\section{Financial Center}

Banks across the U.S. voted in 1913 for their preferred city for branch bank of the new Federal Reserve Baking System. 191 banks in Oregon and Washington submitted their first choice.

$\begin{array}{ll} & 75 \text { picked Portland } \\ & 40 \text { picked Seattle } \\ & 32 \text { picked San } \\ \text { Francisco } & \\ & 26 \text { picked Spokane } \\ & 18 \text { picked other cities }\end{array}$

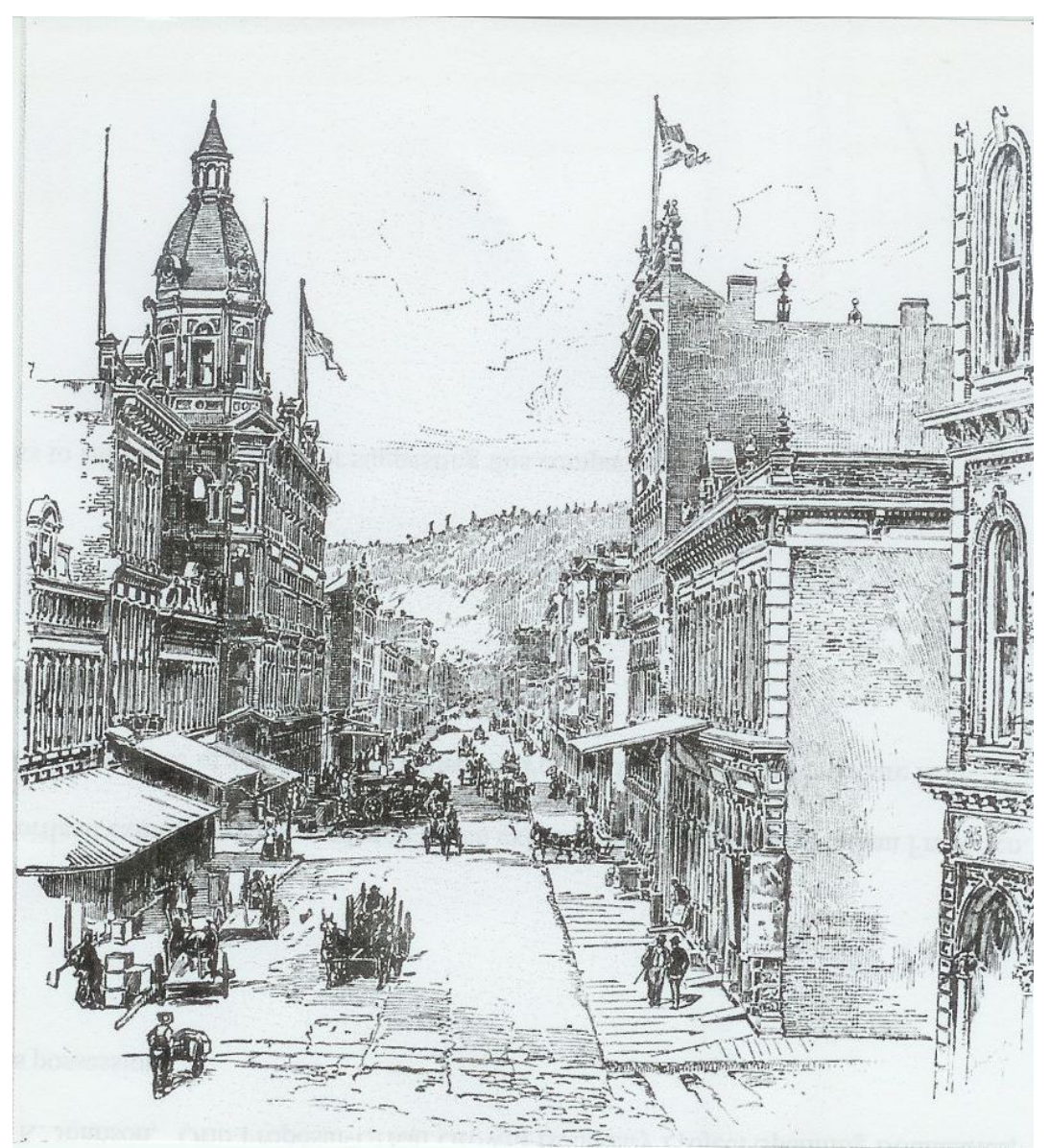




\section{Oregon Cities in 1920: \\ Rank Size Model and Actual Populations}

Oregon Cities 1920: Rank Size Model and Actual Populations

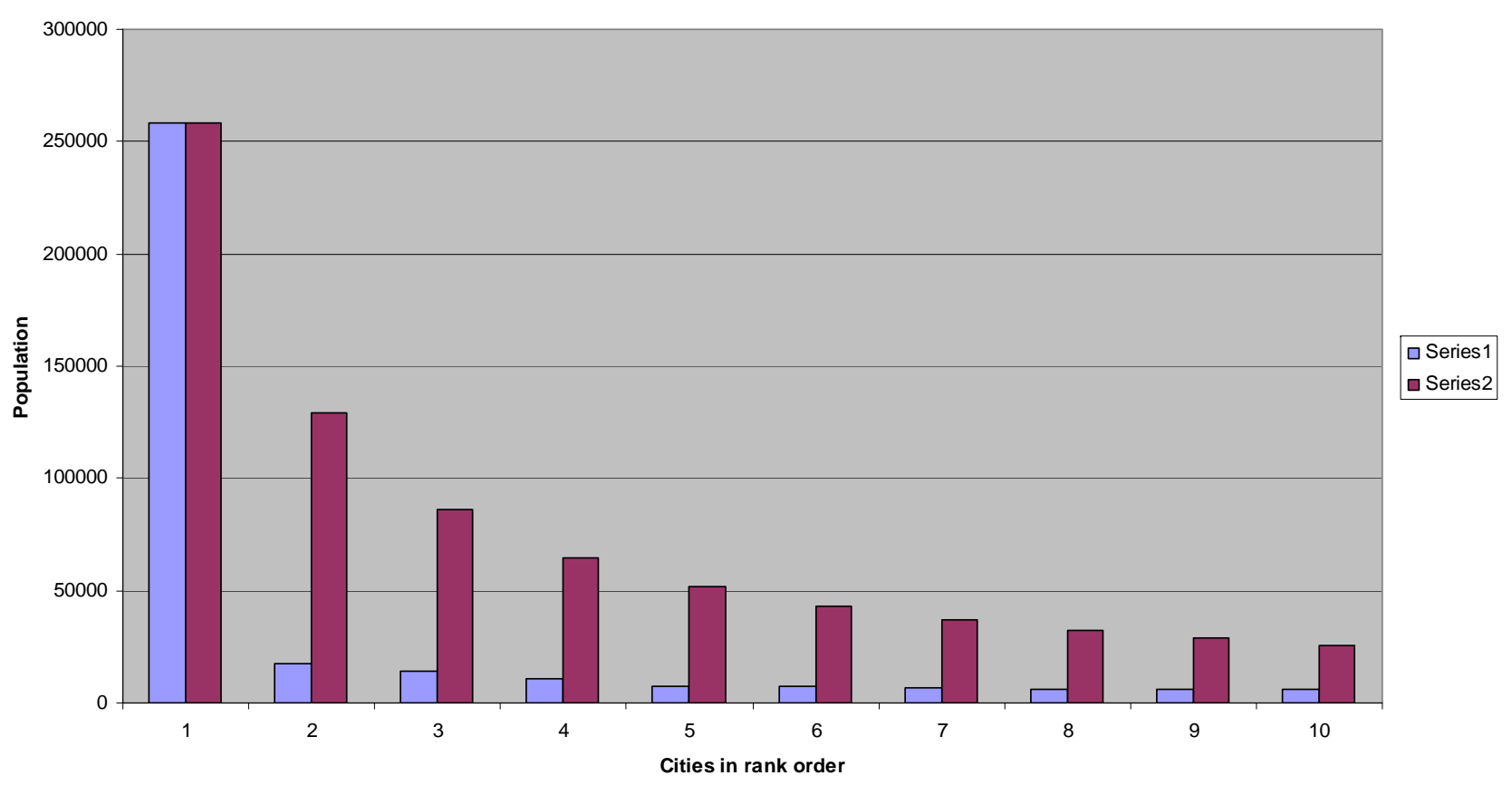

Figure 1 


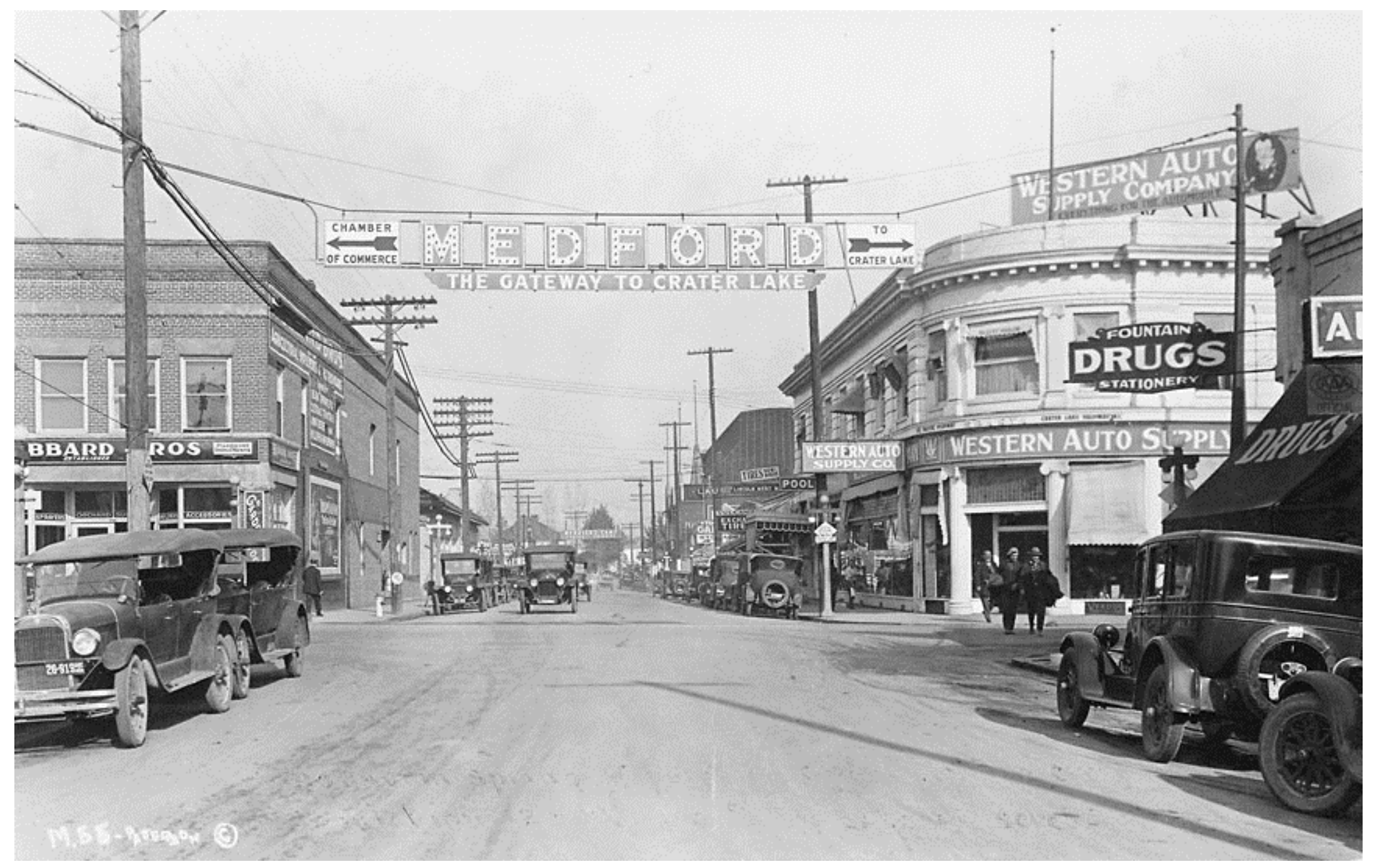




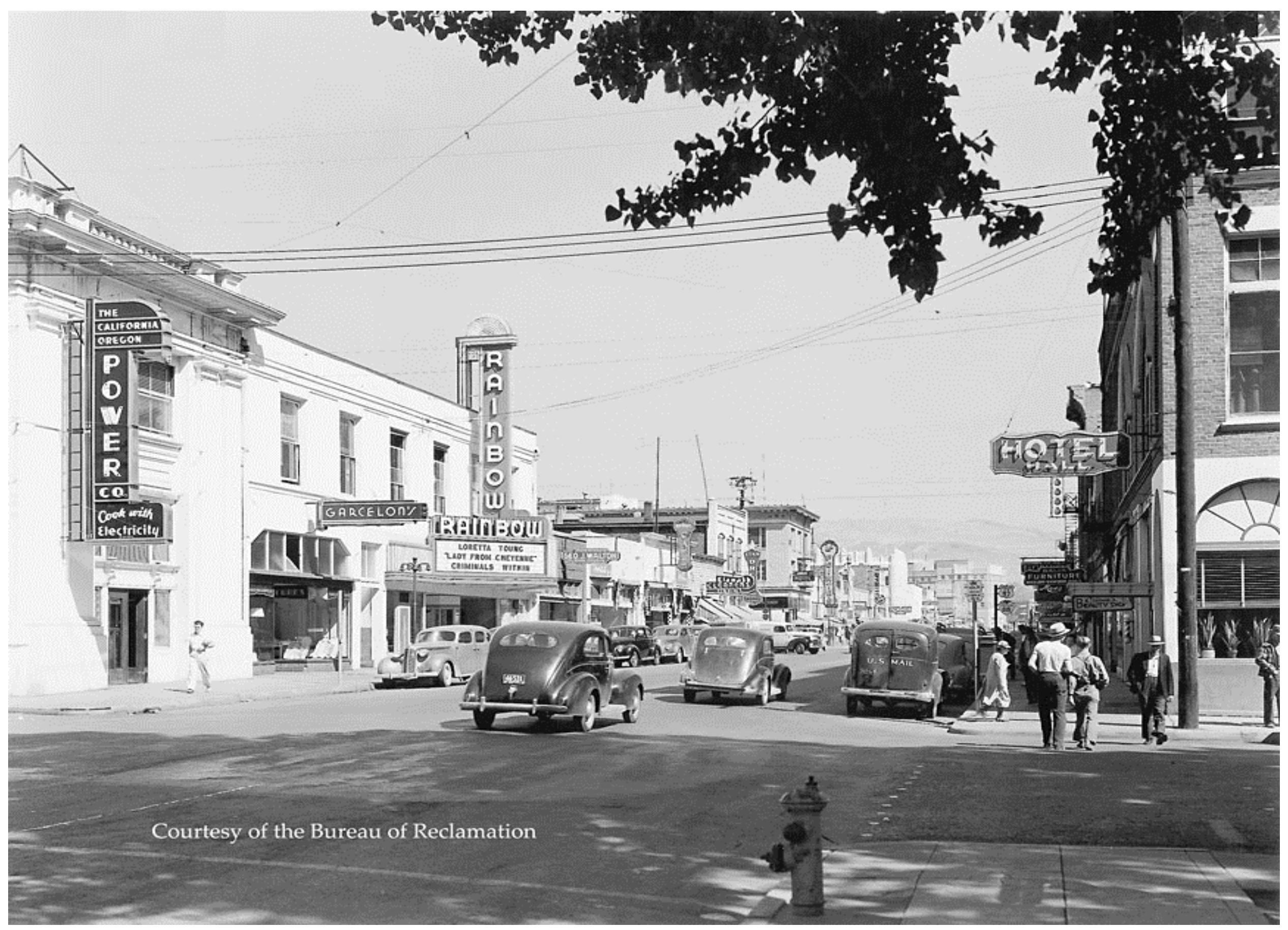




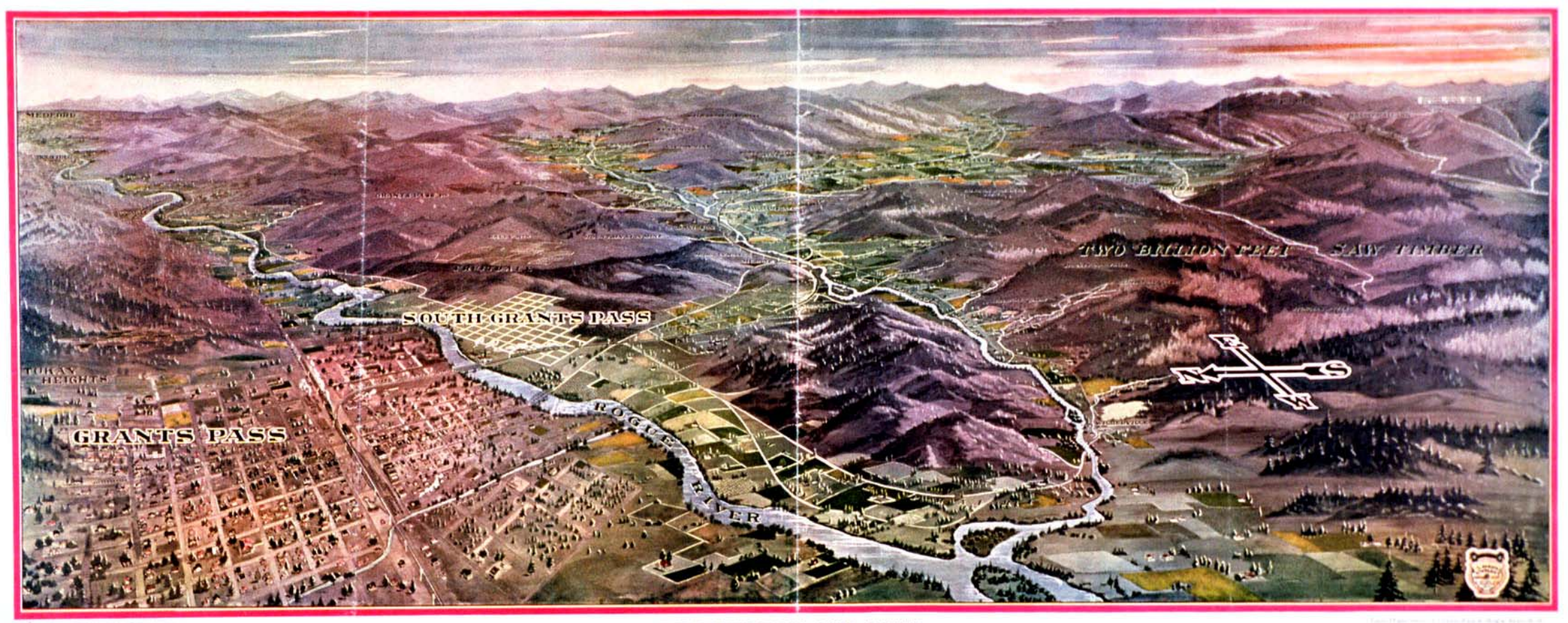

THE FAMOUS ROGUE RIVER VALLEY 


\section{Oregon's Largest Cities: 1940 and 1960}

Portland

Salem

30,908

Eugene

Klamath Falls 16,497

Medford

11,281
305,294 Portland

728,088

Eugene

162,890

Salem

48,142

Medford 24.425

Corvallis $\quad 20,669$

- $\quad$ Portland and Eugene 1960 are metropolitan area populations 


\section{The Common Culture of Natural Resources: \\ Estacada 1949 and Portland 1959}
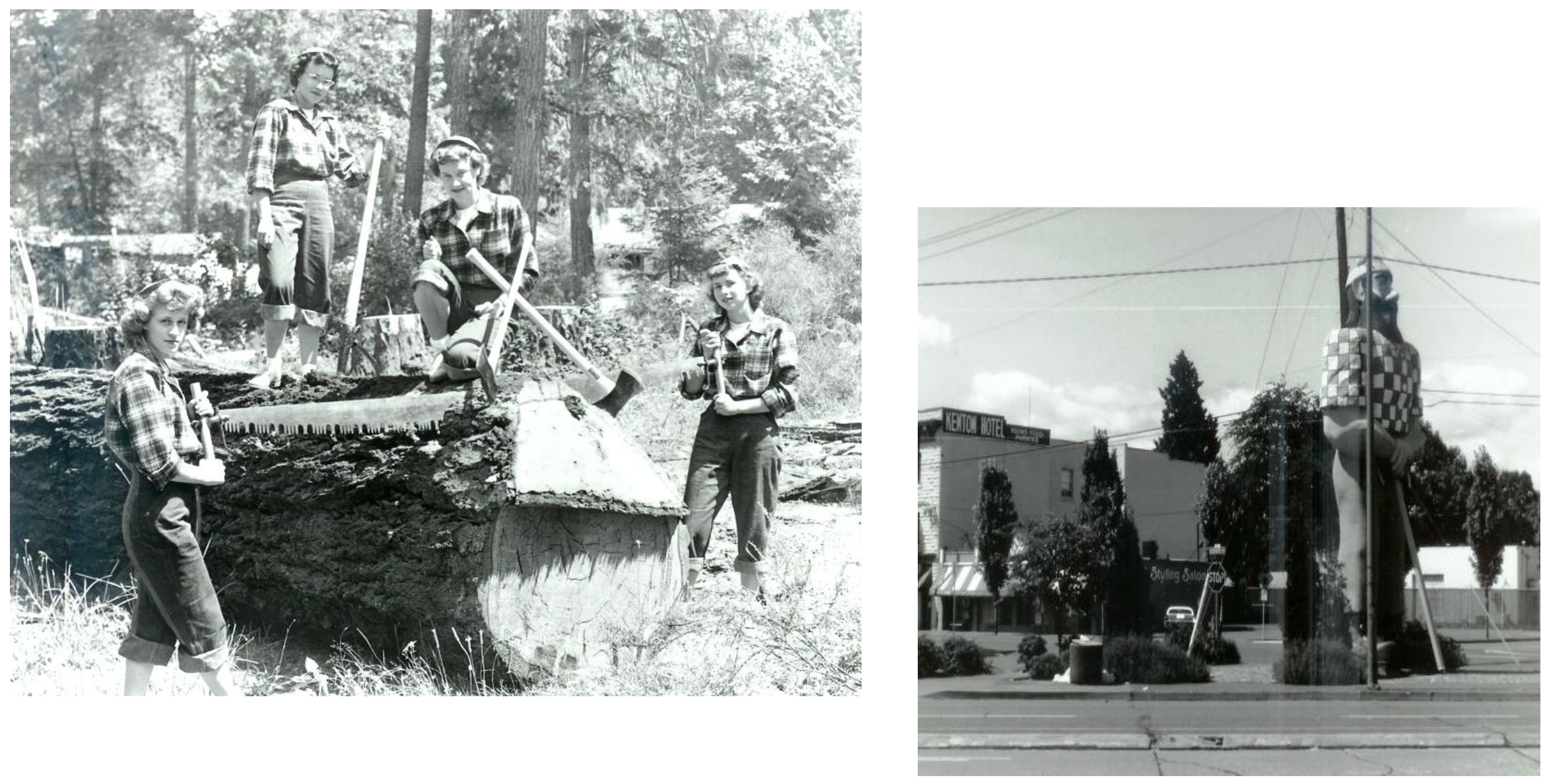


\section{The New Economy of Leisure: The Columbia River Scenic Highway}

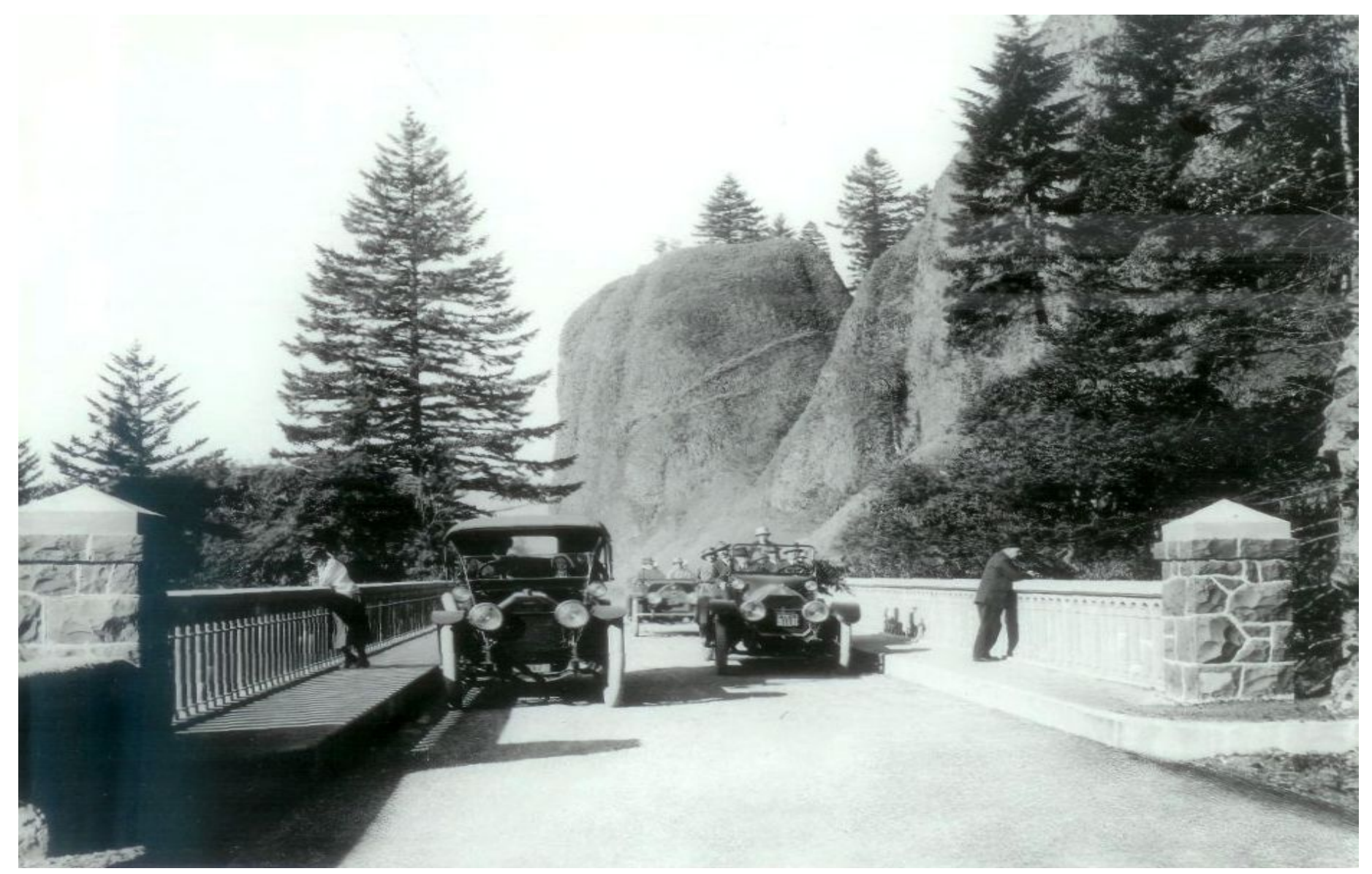




\section{Oregon's Metropolitan Areas, 1980 and 2007}

Portland 1,050,750 Portland 1,734,000

Eugene 275,226 Salem 378,520

Salem 249,895 Eugene 343,140

Medford 132,456 Medford 202,310

Bend $\quad 160,810$

Corvallis $\quad 78.153$ 


\section{Metropolitan Counties}

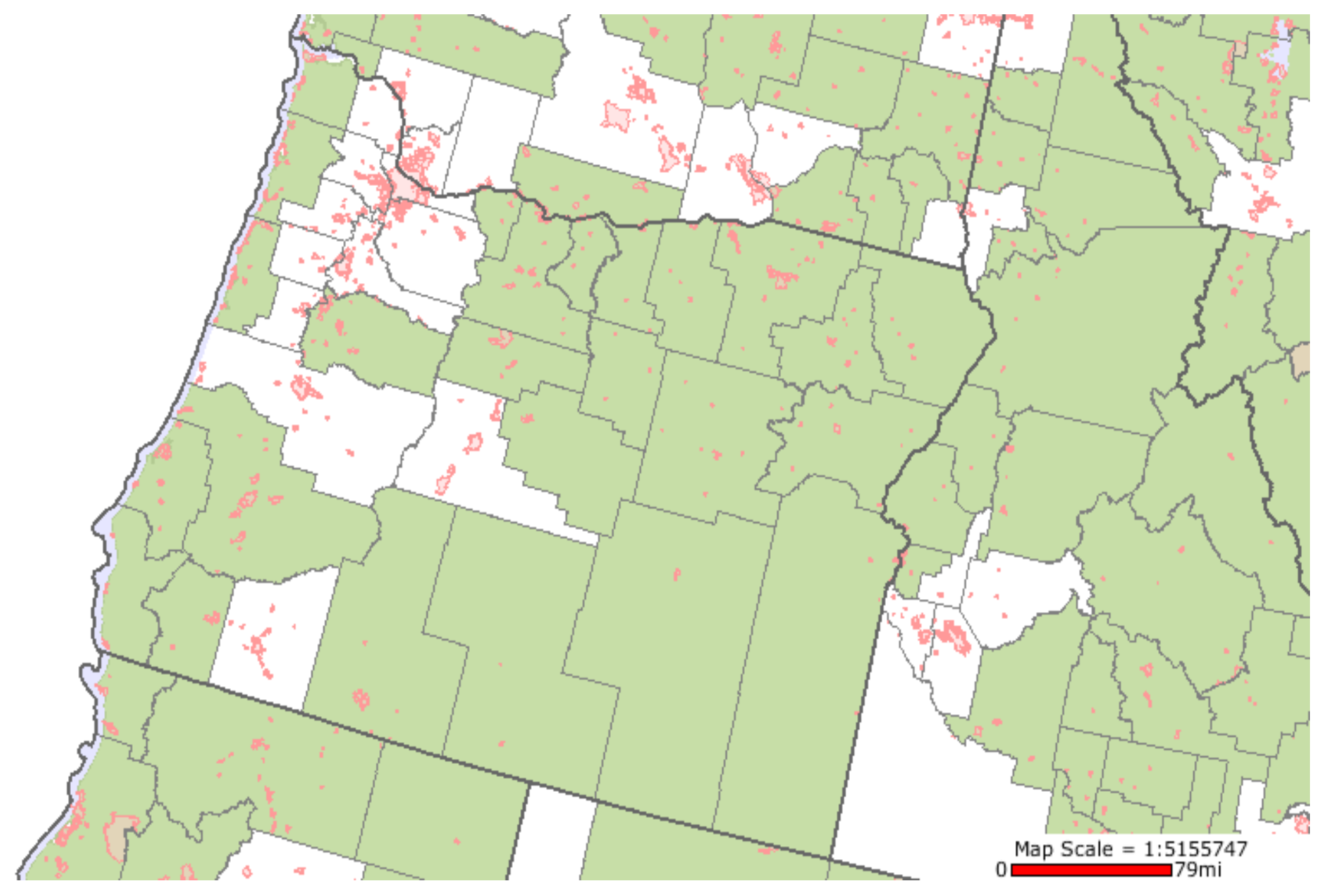




\section{Oregon catches up in the $20^{\text {th }}$ century}

- In 1920, Portland was twice as large as the next twenty cities combined.

- In 1960, Portland was twice as large as the next twelve cities.

- In 2007, the Portland metro area was twice as large as the next two metro areas 


\section{Portland of the Future: 1920s Style}

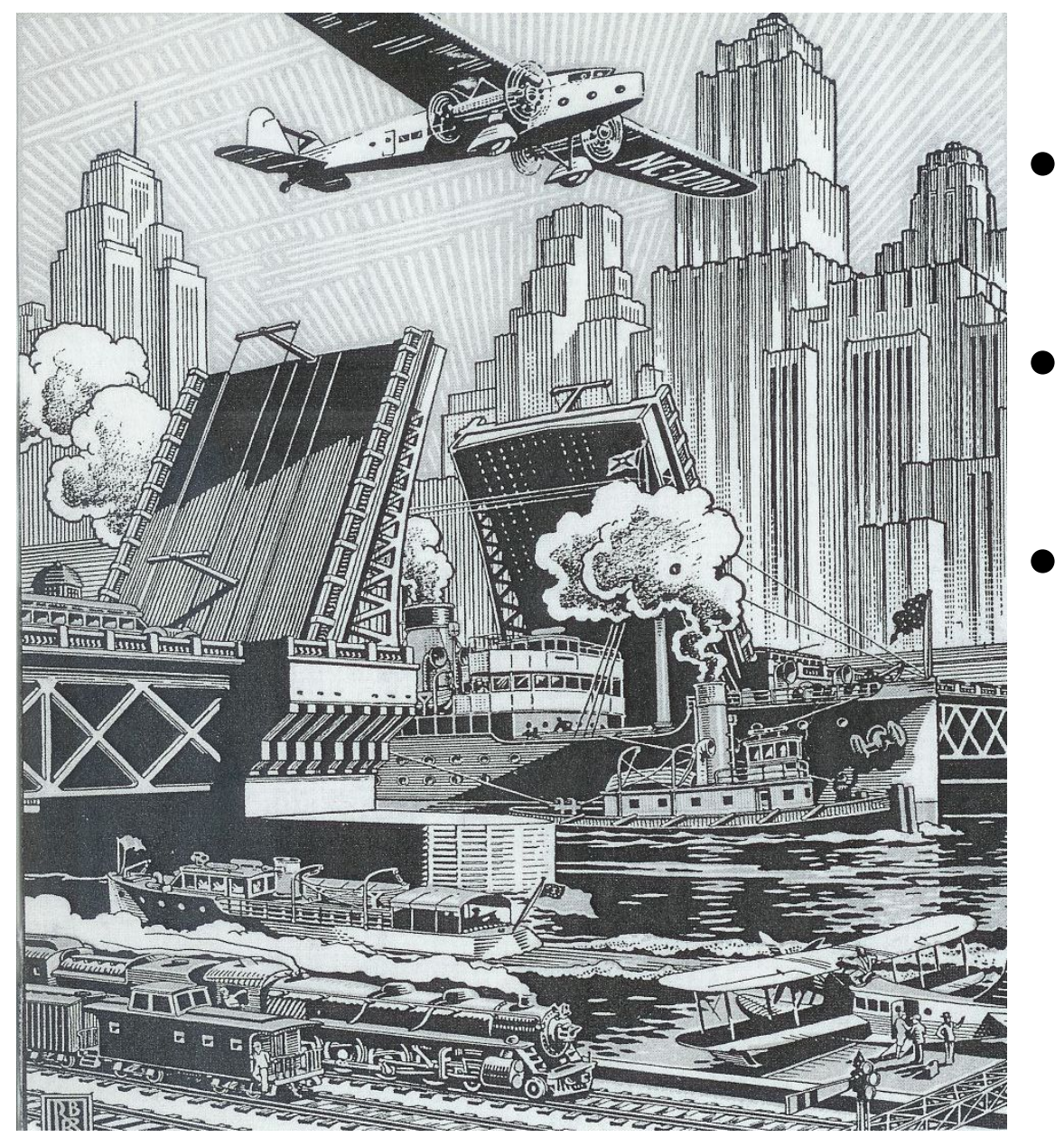

- Skyscrapers for finance and professional services

- Intermodal transportation hub

- Global connections and the promise of the Pacific Rim. 


\section{Two Conclusions}

- What's stayed the same? - What's changed?

- Portland's fundamental services for Oregon were the same in the 1870s, the 1920s, and today.
- Oregon's system of cities is far more equally balanced than it was a century ago. 